International Journal of Social Sciences and Humanities
Available online at www.sciencescholar.us
Vol. 5 No. 3, December 2021, pages: $243-252$
e-ISSN: 2550-7001, p-ISSN: 2550-701X
https://doi.org/10.53730/ijssh.v5n3.2024

\title{
Traditional Pedagogical Trends and Their Impact on the Decline in the Student Population
}

\begin{abstract}
(1) crossmark
Ubety Cedeño Cantos ${ }^{a}$, Yandri Toala Chilan ${ }^{b}$, Ángela Hidrovo Zambrano ${ }^{c}$

Manuscript submitted: 27 September 2021, Manuscript revised: 09 October 2021, Accepted for publication: 18 November 2021

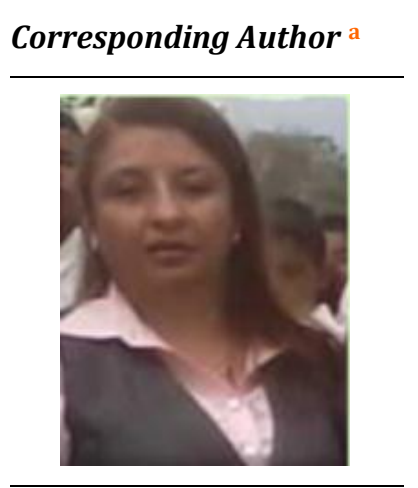

Keywords

education; resources; traditional pedagogy;

Abstract

Traditional education is one of the most common practices in 21st century teachers, despite the advances and efforts made in training and workshops that allow them to strengthen and improve their teaching practice, this has not yet managed to change the conformist bases that produce traditionalism, in this research the traditional pedagogical tendencies and their incidence in the reduction of the student population in high school, of the Honorato Vásquez Fiscal Educational Unit, of the Santa Ana canton, their consequences or effects that generate this type of pedagogy or practice, from an educational reality in the social, economic, cultural, how education is perceived by the authors involved in the educational process and the importance of a pedagogical update. To support the hypothesis, deductive, analytical methodology was used, the application of a brief survey through an online form for the teachers of said institution, the results showed that traditional pedagogy is present in their daily activities, in the direction of content.
\end{abstract} teaching update; didactics;

International Journal of Social Sciences and Humanities (C) 2021.

This is an open access article under the CC BY-NC-ND license (https://creativecommons.org/licenses/by-nc-nd/4.0/).

\section{Contents}

Abstract

1 Introduction

2 Materials and Methods.

3 Results and Discussions....

4 Conclusion

\footnotetext{
a Master's Degree in Educational Innovation, Pontificia Universidad Católica del Ecuador, Portoviejo, Manabí, Ecuador

${ }^{\text {b }}$ Master's Degree in Educational Innovation, Pontificia Universidad Católica del Ecuador, Portoviejo, Manabí, Ecuador ${ }^{c}$ Master's Degree in Educational Innovation, Pontificia Universidad Católica del Ecuador, Portoviejo, Manabí, Ecuador
} 


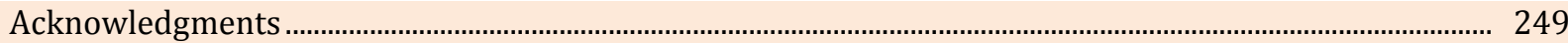

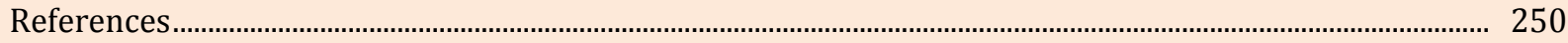

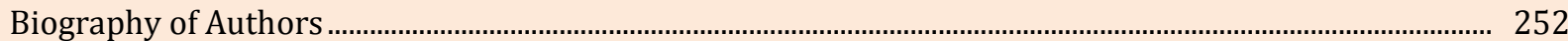

\section{Introduction}

Pedagogy during the beginning of humanity has been present to train, contribute to the development of each locality, city, country, or government, from the great ancient civilizations with the Greek, Egyptian and Chinese have always had a fundamental role in the social and cultural growth of each of them, this conception transmitted by great philosophers such as Plato, Aristotle, Socrates among others, allows us to have a vision of the importance of it. At the beginning of the seventeenth century in France the incorporation of a new way of transmitting knowledge within the academies began to take with great force and it is the so-called Traditional Pedagogy, it is in the seventeenth century where schools emerged as institutions and gave way to pedagogical as sciences, where the educator takes center stage in the teaching-learning process, as established (Rodríguez, 2013).

The traditional school has its significant contributions for being an education that trains and directs the student in ethical, social, and cultural values, which are important aspects to consider in the teaching-learning process, this through teachers who have an analytical trait, systemic, inductive, and deductive. Traditional pedagogy has been the fundamental basis in the education of humanity, but this practice is considered as an expository education, reproductive of information and content, focused only on qualification, the student is a receiving entity, the teacher as the maximum protagonist in the process. From this perspective, traditional pedagogical trends affect the reduction of the student population of an institution, this, due to the need of parents to seek a new teaching model, which allows them to be within social, cultural, and especially expectations in the new educational and innovative proposals that at the present time we are all involved in adapting (Carter et al., 1997; Calderhead, 1989).

Teaching to learn for the development of competencies requires focusing all our attention on the students, which implies a substantial change in the evaluation modalities, requiring the teacher to indicate how their teaching is working (Méndez, 2012). The student is the center in the entire teaching - learning and skills development process, the teacher is the main axis to innovate in the evaluation modality in each evaluation process. Dropout is known as the interruption or disengagement from the institutional academic process carried out by the student. Identifying the factors associated with this phenomenon of desertion is very important, due to the limitation that it can cause in its fulfillment of the fundamental purpose that is to train professionals for life (Ríos Ramírez \& Placencio Macas, 2018).

School dropout is common at all levels of education from initial to university careers, this is due to many factors that affect the decision of students and their environment where they develop day by day, whether it is done in a forced or voluntary way. In Ecuador, in many areas the problems with dropping out have been considered, fundamentally during the pandemic, where many students for different reasons have dropped out of school (Pachay et al., 2020). It can be asserted that dropping out of school brings with it consequences that are reflected in the emotional, social, cultural, affective, family, of the actors of the teaching-learning process due to factors that allow truncating dreams and wishes (Restrepo, 2010).

The Ministry of Education of Ecuador must implement alternatives that allow counteracting the problem of school dropout or dropout since it brings many negative consequences for society, the family and the student that allow it to do so. Authors such as Godínez et al. (2015), point out that, the family, and the environment where the students develop is a fundamental pillar to motivate and encourage children, adolescents, valuing the opportunities in their academic context despite the limitations that allows you to achieve your goals with a level of knowledge according to your reality (Tamir, 1988; Mahoney, 1995).

The teaching-learning strategies used by the teacher so that students understand and learn the contents, allow them to instruct themselves, carry out their tasks, developing and expressing what they have learned in the activities, for Domínguez et al. (2017), learning strategies are processes of taking of decisions, in which the student chooses and recovers the knowledge he needs to complete a task. These strategies are personal procedures that allow, on the one hand, the control, selection and execution of methods and techniques for the 
processing of information; and on the other, planning, evaluating and regulating the cognitive processes involved in said process (Powell, 1992; Toothaker \& Taliaferro, 2017).

\section{Materials and Methods}

The reflective and analytical methodology was used from the experience and lived events of how traditional pedagogy is impregnated in the didactic genetics of teachers, a survey was applied to 10 teachers of the Fiscal Educational Unit Honorato Vásquez, of Cantón Santa Ana, to know to what extent traditionalism is applied in their pedagogical activities and in what indirect way it affects the reduction of the student population of said institution. The bibliographic review method was used, where the positions of various authors who scientifically argue the research were consulted and with this strengthen the analytical criteria used in each of the reflections (Oxford, 1993; Rubin \& Smith, 1990).

\section{Results and Discussions}

The research work was developed in an Educational Unit of the Santa Ana Canton, Manabí province, where it has been noted that, in recent years, a significant decrease in the student population has been reflected, finding that there several factors influencing this cause, that shown in Figure 1.

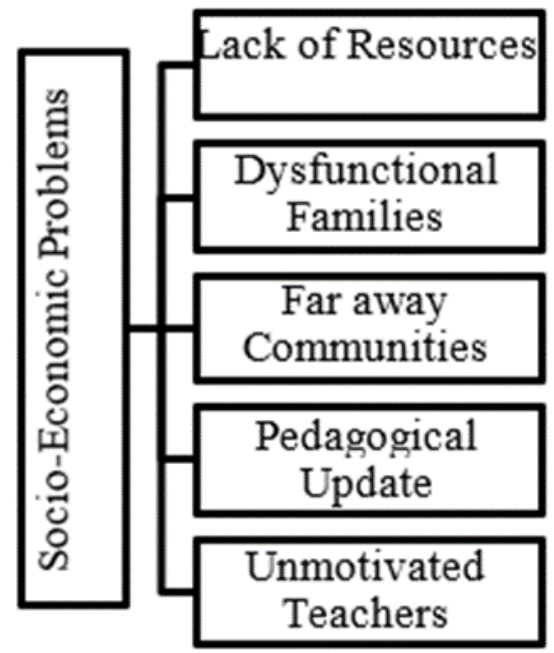

Figure 1. Socioeconomic conditions in the environment of students

These conditions significantly influence the educational process, one family, who is the cornerstone for the adequate growth in values of children and young people during this stage. The family is the educational center of importance for the student, within it the appropriate conditions for their development are established, providing them with the tools and mechanisms in each of their stages (Espitia Carrascal \& Montes Rotela, 2009). In order to counteract the inconveniences of children in the family environment, they must be made to attend schools or colleges to motivate their schooling processes, with teachers who innovate and adapt new strategies according to the needs of society (Collis, 1998; González-García et al., 2019).

\section{The teaching reality}

The teachers of the Fiscal Education Unit Honorato Vásquez, in their teaching practice implement traditional pedagogical strategies, which demotivate the student during the teaching-learning process and especially does not reflect the social reality that they must face. This practice has caused a significant effect in the

Cantos, U. C., Chilan, Y. T., \& Zambrano, Ángela H. (2021). Traditional pedagogical trends and their impact on the decline in the student population. International Journal of Social Sciences and Humanities, 5(3), $243-252$. 
decrease of the student population during the last 3 years, parents and the community in general conceptualize the education provided as: out of reality and social need, boring exhibitions, they only dedicate themselves to the Boys transcribe what is in the books, little work is done on projects proposed by the teacher, only those that are required by the Ministries of Education are executed, they do not update their knowledge, and they do not allow the interaction of current ideas. This reality is the fruit of the traditional teacher, one who is afraid to update, innovate who is content only to comply with his work schedule, keep the classroom in total silence. With the advances in technologies, new communication and preparation tools have been incorporated, whether these are virtual or face-to-face, this is where the real problem of teaching awareness in their practice lies: the lack of updating knowledge and adaptation to advances technological. Figure 2 shows the reality of teachers and their traditional practice.

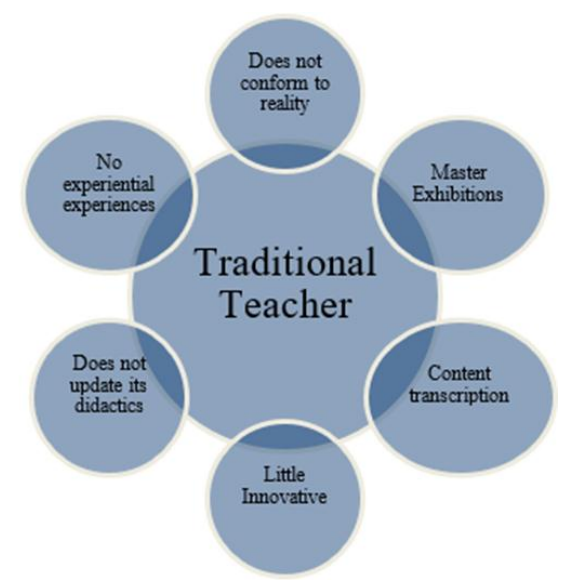

Figure 2. The teaching reality and its traditional practice

Each of these aspects have had a direct impact on the reduction of student participation in classrooms, so that the enrolled population has decreased (Peter, 2015; Maba et al., 2018).

\section{Teaching updating}

The efforts made by the Ministry of Education in teaching updating have allowed many to improve their pedagogy and didactics for the well-being of the entire community that surrounds them and that is part of it. Another existing reality that is present in the Educational Unit, several teachers during the call to training courses, do not appear, do not consciously perform their role as professionals of being in constant preparation of new content and tools, to This is looking for acquaintances, colleagues, friends so that they can take the course, seminars and approve them, others instead wait for the evaluations to be resolved to present and pass, they are only interested in the certificate but not the knowledge they must acquire.

A survey was applied to 10 teachers to confirm how traditional pedagogy is still present in the practice of the teachers of the Fiscal Education Unit Honorato Vásquez and how it affects the decrease in the student population in high school. One of the current problems of teachers is that they do not apply didactics in the classroom. Table 1 shows the results of the survey.

Table 1

Type of didactics applied by the teacher

\begin{tabular}{lcc}
\hline \multicolumn{1}{c}{ Variables } & Teacher & Percentage (\%) \\
\hline Inverted classroom & 4 & 40 \\
Use the student's text as a guide & 6 & 60 \\
\hline
\end{tabular}

The trend is that $60 \%$ of teachers, during their classes only guide themselves with the text of the student, giving a vision of the way in which, they maintain a transmission of knowledge in a traditional way, they do not look for new resources, content, and strategies for which they try to fulfill their task based on proposed 
topics. 40\% apply the flipped classroom technique, where students are the protagonists of their learning and the teacher guides them in this process, who is constantly updated to provide feedback once the intervention is finished. The master classes are not used by teachers since there was no selection of it. Teachers were consulted on how they apply their didactics in the classroom, there are authors who value the types of didactics, for Mayorga Fernández \& Madrid Vivar (2010), it is from providing the appropriate pedagogical tools in the teaching-learning process, which allows the student to apply their knowledge for the benefit of all and in the development of their skills. In figure 3, the results of how the evaluation is carried out in the classrooms are shown.

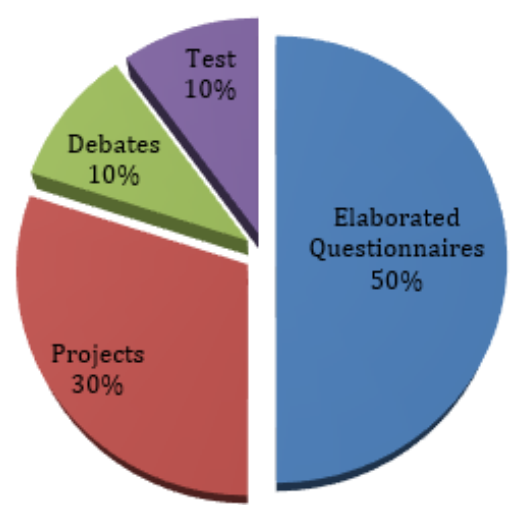

Figure 3. Types of evaluations applied by the teacher

The Teaching Competences Assessment Model (MECD) according to (Enriquez \& Romero takes up the knowledge of teaching performance evaluation practices in various universities, both public and private; it has been proposed with the purpose of guiding the activities of teachers and managers in the evaluation processes, $50 \%$ of teachers evaluate the knowledge of their students with the elaboration and application of questionnaires, based on closed, objective, open questions, which to some extent can determine if the level of knowledge of the group of students is appropriate or not and for $30 \%$, the projects are the best way to evaluate the knowledge in the students, with this you can generally appreciate their abilities with the approach of a problem. Table 3. The type of strategies used by the teacher, for the presentation of the group activities of the students:

Table 3

Strategies used by the doc entity, for the presentation of the group activities of the students

\begin{tabular}{lcc}
\hline \multicolumn{1}{c}{ Variables } & Teaching & Percentage (\%) \\
\hline Flipnotes & 8 & 80 \\
Slides & 2 & 20 \\
\hline
\end{tabular}

The presentation of work in groups or presentations made by students, the teacher allows the use of flipcharts, a trend that is marked in $80 \%$ of the results obtained, despite executing the teamwork, these results have become static and traditionalist, $20 \%$ request that their students present their group work in slides, with which the interventions will be dynamic and motivating. The didactic strategies that have contributed significantly, especially to the knowledge and critical analysis of the students are master class, brainstorming, round table, dynamics and repeating the most important in each topic that is explained (López \& Vera, 2019). In figure 4 , the results of how the control of behavior in the classroom is the main thing for teachers are expressed.

Cantos, U. C., Chilan, Y. T., \& Zambrano, Ángela H. (2021). Traditional pedagogical trends and their impact on the decline in the student population. International Journal of Social Sciences and Humanities, 5(3), 243-252. 


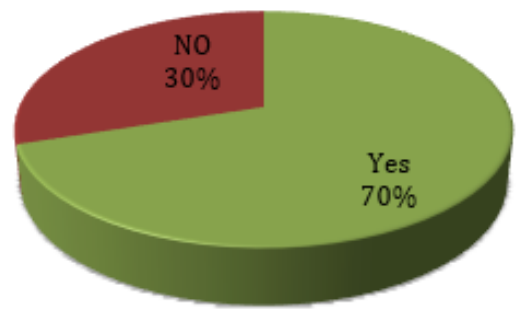

Figure 4. Behavior within the classroom

One of the main aspects of traditionalism is to maintain and control behavior within the classroom, $70 \%$ of the respondents confirm that it is necessary, but this must be a perspective very different from the process, conduct or discipline can be managing with an innovative class that engages the student and keeps him attentive, participatory, collaborative throughout the duration, $30 \%$ pay more attention to how the content is addressed than to maintain behavior in the classroom. Table 5 shows the knowledge of the pedagogical proposal or pedagogical model of the Ministry of Education of Ecuador, according to the curriculum implemented in 2016.

Table 5

Pedagogical model and curriculum of the ministry of Education of Ecuador

\begin{tabular}{lcc}
\hline \multicolumn{1}{c}{ Variables } & Teaching & Percentage (\%) \\
\hline Socio-Constructivist & 3 & 30 \\
New School & 2 & 20 \\
Cognitive Model & 1 & 10 \\
Constructivist Model & 4 & 40 \\
\hline
\end{tabular}

One of the serious shortcomings within the Educational System is the ignorance in teachers of the Educational Model that directs their practice, there is 30\% who know our Educational Model is Socio-Constructivist, $20 \%$ believe that it is a New School Model, for $10 \%$ it is a Cognitive Model and while $40 \%$ determine that it is a Constructivist Model. From these various positions it allows us to deduce that among teachers there is no such thing as how is our teaching directed from the Model proposed in our country? This effect gives rise to the fact that the work carried out is diverse and, in many cases, erroneous for the new demands and needs of today's society. The current pedagogical model presided over by the Ministry of Education of the Republic of Ecuador is the Model of the Bilingual Intercultural Education System (MOSEIB), which highlights the integration of the country's cultural and linguistic diversity (Ministry of Education, 2021). In figure 5, it is observed what type of technological tool the teachers use in their classes.

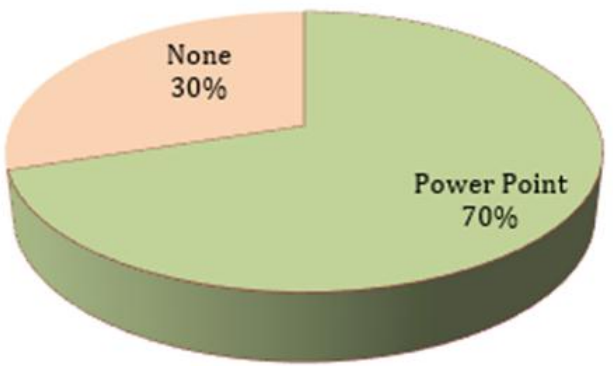

Figure 5. Use of the Tool in the docents

Technological tools within a classroom enable new modes of knowledge, learning and communication. As well as communicating to human beings in real time, through technological platforms in different study modalities Rizales Semprum et al. (2019), a marked trend of $70 \%$ of the consulted population states that it is their 
planning, content preparation, make use of tools such as Power Point, this being a tool that is used recurrently within the educational field, however there is no domain or use of other novel and innovative applications that would allow the creation of interactive content, is reflected in the $30 \%$ of the results obtained. Table 7 shows the educational aspects in students, considered by teachers in the teaching-learning process.

Table 7

Educational aspects in students

\begin{tabular}{lcc}
\hline \multicolumn{1}{c}{ Variables } & Teaching & Percentage (\%) \\
\hline Reflective & 6 & 60 \\
Dynamic & 2 & 20 \\
Questioners & 2 & 20 \\
\hline
\end{tabular}

To a large extent the pedagogical didactics in teachers is traditionalist, within their professional motivations they consider reflective students important in their classrooms, $60 \%$ confirm it, for those who are dynamic or questioning a $20 \%$ relevance is established, the rote do not play a leading role in the development of skills. Teachers must establish within their didactic resource that encourages cognitive development in their students, respecting styles, and ways of learning (Hurtado et al., 2017).

\section{Conclusion}

Traditional pedagogy still maintains a brief domain within the educational system, in the Educational Unit under investigation, teachers do not update their knowledge in technological, pedagogical and didactic tools. One of the problems faced by an institution with traditional education is the decrease in the student population, where parents and students look for educational establishments that train them with current approaches and according to the socio-technological advances that satisfy their needs.

Acknowledgments

We are grateful to two anonymous reviewers for their valuable comments on the earlier version of this paper.

Cantos, U. C., Chilan, Y. T., \& Zambrano, Ángela H. (2021). Traditional pedagogical trends and their impact on the decline in the student population. International Journal of Social Sciences and Humanities, 5(3), $243-252$. https://doi.org/10.53730/ijssh.v5n3.2024 


\section{References}

Calderhead, J. (1989). Reflective teaching and teacher education. Teaching and teacher education, 5(1), 43-51. https://doi.org/10.1016/0742-051X(89)90018-8

Carter, N. M., Williams, M., \& Reynolds, P. D. (1997). Discontinuance among new firms in retail: The influence of initial resources, strategy, and gender.Journal of business venturing,12(2), 125-145. https://doi.org/10.1016/S0883-9026(96)00033-X

Collis, B. (1998). New didactics for university instruction: why and how?. Computers \& Education, 31(4), 373393. https://doi.org/10.1016/S0360-1315(98)00040-2

Domínguez, ECA, Sellan, MAM, Gavino, CNF, \& Guerrero, MML (2017). The role of the family and teachers in the prevention and educational inclusion of adolescents with addiction problems. In Memories of the third International Congress of Pedagogical Sciences: For an inclusive education: with all and for the good of all (pp. 612-622). Bolivarian Higher Technological Institute.

Espitia Carrascal, R. E., \& Montes Rotela, M. A. R. I. V. E. L. (2009). Family influence in the educative process of minors in the Costa Azul neighbourhood of Sincelejo (Colombia). Investigación y Desarrollo, 17(1), 84-105.

Godínez, G., \& Alarcón, M., \& García, V. (2015). Cause of school dropout of women from an emotional health perspective Investigations, strategies and means in educational practice / coord. by Francisco Santillán Campos, ISBN 978-607-8435-03-6, pp. 106-117

González-García, N., Sánchez-García, A. B., Nieto-Librero, A. B., \& Galindo-Villardón, M. P. (2019). Attitude and Learning Approaches in the Study of General Didactics. A Multivariate Analysis. Revista de Psicodidáctica (English ed.), 24(2), 154-162. https://doi.org/10.1016/j.psicoe.2019.03.001

Hurtado, P., Támez, R., \& Lozano, A. (2017). Characteristics presented by students with different learning styles in collaborative learning environments, Pedagogical Trends,30, 191-206. Retrieved from https://dialnet.unirioja.es/servlet/articulo?codigo=6164823

López, M., \& Vera, A. (2019). Characterization of the didactic strategies developed by excellent teachers in Ecuador. Areté: Digital Magazine of the Doctorate in Education of the Central University of Venezuela , 5 (10), 27-44.

Maba, W., Perdata, I. B. K., Astawa, I. N., \& Mantra, I. B. N. (2018). Conducting assessment instrument models for teacher competence, teacher welfare as an effort to enhance education quality. International Research Journal of Management, IT and Social Sciences, 5(3), 46-52. Retrieved from https://sloap.org/journals/index.php/irjmis/article/view/170

Mahoney, J. T. (1995). The management of resources and the resource of management. Journal of business research, 33(2), 91-101. https://doi.org/10.1016/0148-2963(94)00060-R

Mayorga Fernández, M. J., \& Madrid Vivar, D. (2010). Didactic Models and Teaching Strategies in the European Higher Education Area.

Mendez, J. (2012). New trends in Online Education The new University.

Ministry of Education. (2021). Model and Curriculum of the Education System. Quito, Pichincha, Ecuador.

Oxford, R. L. (1993). Research update on teaching L2 listening. System, 21(2), 205-211. https://doi.org/10.1016/0346-251X(93)90042-F

Pachay López, M. J., Rodríguez Gámez, M., \& Vera Pachay, L. M. (2020). Cooperative learning an innovative active methodology. Atlante Cuadernos de Educación y Desarrollo, (August).

Peter, V. F. (2015). Relationship among culture, education and sports. International Research Journal of Management, IT and Social Sciences, 2(11), 38-42. Retrieved from https://sloap.org/journals/index.php/irjmis/article/view/326

Powell, R. R. (1992). The influence of prior experiences on pedagogical constructs of traditional and nontraditional preservice teachers. Teaching and teacher education, 8(3), 225-238. https://doi.org/10.1016/0742-051X(92)90022-U

Restrepo, A. (2010). Factors related to student dropout in the nursing program at the libre university of pereira.

Ríos Ramírez, S., \& Placencio Macas, M. S. (2018). Rol De Los Docentes En La Disminucioìn De La Deserciòn Estudiantil En La Carrera Tecnico Superior En Enfermerìa Del Instituto Superior Tecnologico Bolivariano.

Rizales-Semprum, M. J., Gómez-Valderrama, C. L., \& Hernández-Suarez, C. A. (2019). Uso de herramientas tecnológicas para la enseñanza de la ciencias en educación media diversificada de acuerdo a la modalidad de estudio a distancia. Eco Matemático, 10(2), 35-46. 
Rodríguez, J. (2013). A look at traditional and humanist pedagogy. University presence.

Rubin, D. L., \& Smith, K. A. (1990). Effects of accent, ethnicity, and lecture topic on undergraduates' perceptions of nonnative English-speaking teaching assistants. International journal of intercultural relations, 14(3), 337-353. https://doi.org/10.1016/0147-1767(90)90019-S

Tamir, P. (1988). Subject matter and related pedagogical knowledge in teacher education. Teaching and teacher education, 4(2), 99-110. https://doi.org/10.1016/0742-051X(88)90011-X

Toothaker, R., \& Taliaferro, D. (2017). A phenomenological study of millennial students and traditional pedagogies. Journal of Professional Nursing, 33(5),

345-349. https://doi.org/10.1016/j.profnurs.2017.01.004

Cantos, U. C., Chilan, Y. T., \& Zambrano, Ángela H. (2021). Traditional pedagogical trends and their impact on the decline in the student population. International Journal of Social Sciences and Humanities, 5(3), 243-252. https://doi.org/10.53730/ijssh.v5n3.2024 


\section{Biography of Authors}

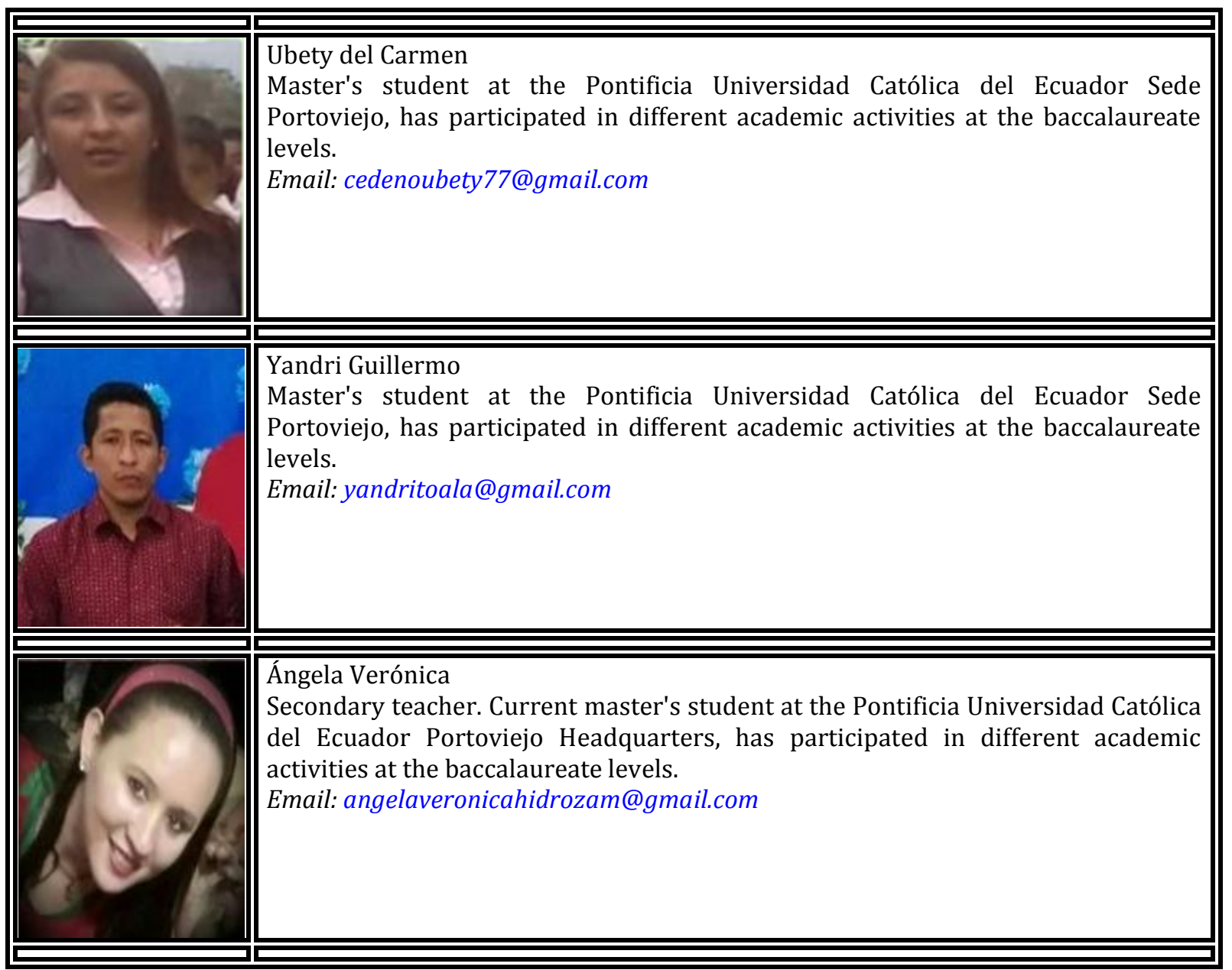

